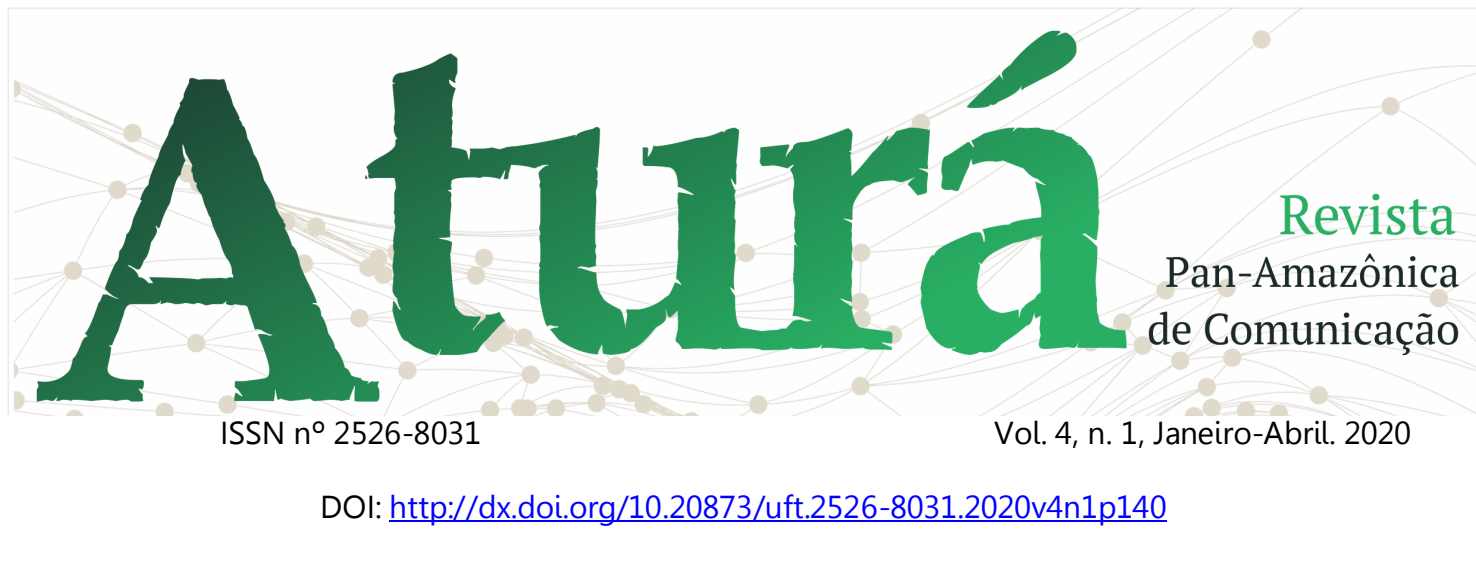

\title{
YOUTUBER MIRIM EM BELÉM: o consumo que encanta
}

CHILD YOUTUBER IN BELÉM: the consumption that delights

YOUTUBER MIRIM EN BELÉM: Consumo encantador

\section{Danuta de Cássia Leão ${ }^{1}$ \\ Ivana Claudia Guimarães Oliveira ${ }^{2,3}$}

\section{RESUMO}

O objetivo deste trabalho é pensar como se dão as produções e interações das crianças com a plataforma digital YouTube, em análise sobretudo os que dizem respeito as relações mercadológicas e comunicacionais deste "eu" no mundo digital. Assim, este artigo analisa a criança enquanto sujeito social e sua relação com a mídia YouTube. A análise foi feita a partir da revisão bibliográfica para se entender o YouTube e o consumo digital e a partir do conteúdo de canais foi possível entender a dinâmica da linguagem espetacular produzida por eles, para cativar suas audiências, a fim de compreender a importância do lugar que a infância ocupa na contemporaneidade digital.

PALAVRAS-CHAVE: Infância; YouTuber mirim; Consumo; Espetáculo; Digital

\footnotetext{
${ }^{1}$ Doutoranda do Programa de Pós-graduação Comunicação, Cultura e Linguagens (PPGCLC), da Universidade da Amazônia- UNAMA. Professora do Curso de Publicidade e Propaganda da Universidade da Amazônia- UNAMA e professora da Faculdade de Estudos Avançados do Pará- FEAPA. Pesquisadora do Grupo de Pesquisa Consumo, Identidade e Amazônia (CONSIA / CNPq).E-mail: danutaleaopp@gmail.com.

2 Doutora em Ciências: Desenvolvimento Sustentável do Trópico Úmido pelo Núcleo de Altos Estudos Amazônicos da Universidade Federal do Pará. Professora do Programa de Pós-Graduação Comunicação, Cultura e Linguagens, da Universidade da Amazônia - UNAMA. Integrante do grupo de pesquisa Narrativas Contemporâneas na Amazônia Paraense (UFPA/UNAMA). E-mail: ivana.professora@gmail.com.

${ }^{3}$ Endereço de contato com os autores (por correio): Universidade da Amazônia, Av. Alcindo Cacela, 287 - Umarizal. Belém - Pará, Brasil. CEP 66060-900.
} 


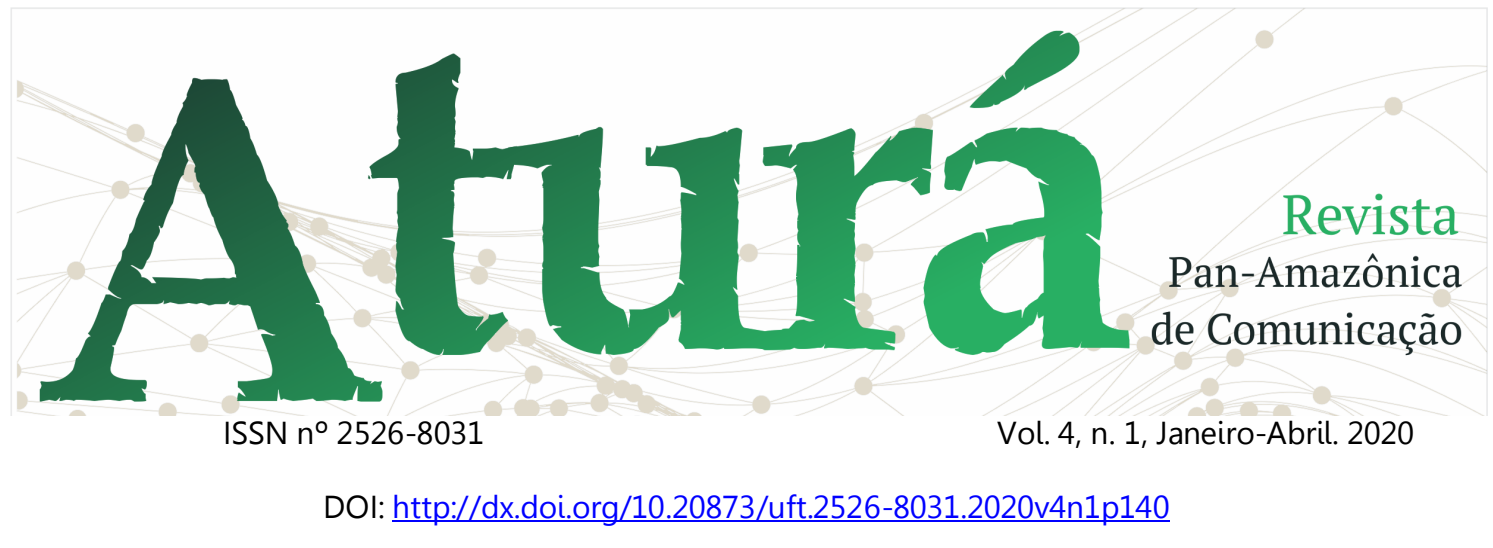

\begin{abstract}
This study aims to think how children productions and interactions happen in the YouTube digital platform, especially those concerning the marketing and communicational relations about this "self" in the digital world. Thus, this study analyzes the child as a social subject and his relationship with YouTube platform. The analysis is made with the literature review to understand YouTube and digital consumption and starting from the channels content it was possible to understand the dynamics of the spectacular language produced by them, to captivate their audiences, in order to understand the importance of the childhood role occupies in the digital contemporary.
\end{abstract}

KEYWORDS: Childhood; Child YouTuber; Consumption; Spectacle; Digital

\title{
RESUMEN
}

El objetivo de este artículo es pensar en cómo las producciones e interacciones de los niños con la plataforma digital YouTube, especialmente aquellas relacionadas con las relaciones de marketing y comunicación de este yo en el mundo digital. Por lo tanto, este artículo analiza al niño como sujeto social y su relación con los medios de YouTube. El análisis se realizó a partir de la revisión de la literatura para comprender YouTube y el consumo digital, y del contenido de los canales fue posible comprender la dinámica del lenguaje espectacular producido por ellos, cautivar a sus audiencias para comprender la importancia del lugar. que la infancia ocupa en lo digital contemporáneo.

PALABRAS CLAVE: Infancia; YouTuber niño; Consumo; Mostrar Digital

Recebido em: 12.11.2019. Aceito em: 12.12.2019. Publicado em: 03.01.2020. 


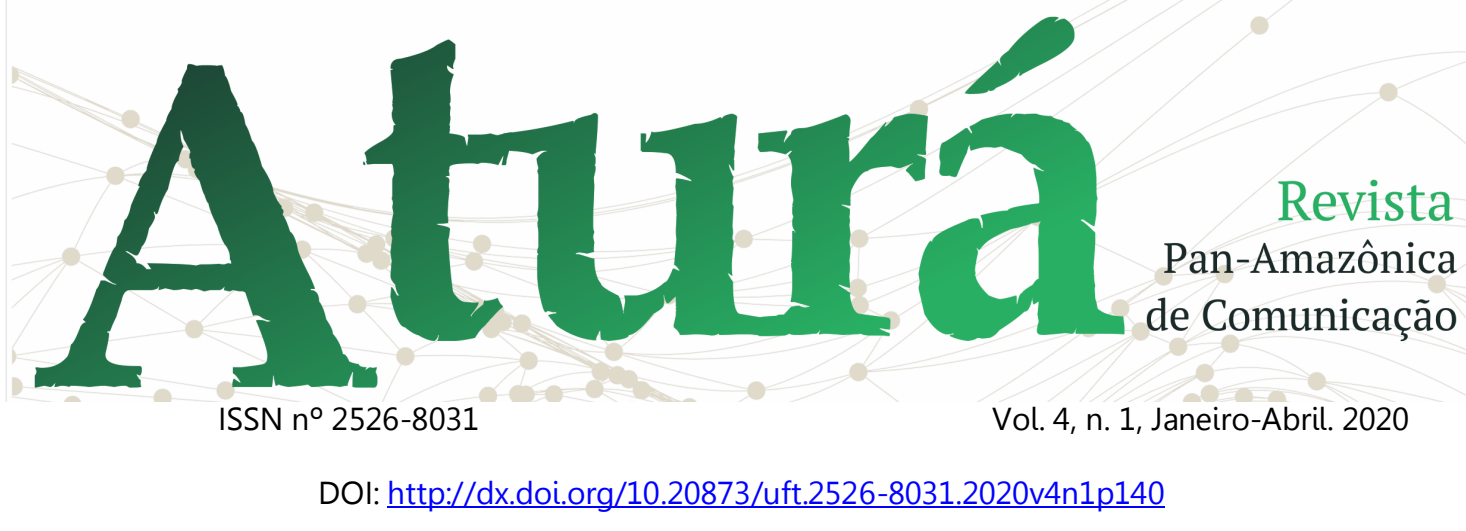

\section{Contextualização}

Com o avanço da internet surgiu uma comunicação muito mais interativa, caracterizada pelo envio de mensagens de um para muitos. Em tempo real ou escolhido. A televisão continua enquanto mídia de massa, mas ela foi profundamente transformada pela tecnologia e seus conteúdos tiveram que se adequar à era da convergência e transformar seus produtos mais atrativos aos telespectadores que possuem agora múltiplas telas.

A internet transformou a televisão na medida em que adolescentes e crianças assistem seus programas inteiros de televisão na tela de seus computadores e celulares. A televisão, de acordo com o pensamento de Castellls (2015), continua importante enquanto mídia de massa, mas seu fornecimento e seu formato estão sendo transformados à medida que a recepção se individualiza.

Assim como outros sites de conteúdo gerado por usuários, o YouTube é um meio de uma mídia de massa, mas segundo Castells (2015) ele se difere da mídia tradicional, pois qualquer pessoa pode postar um vídeo com poucas restrições. E o usuário seleciona o vídeo que deseja assistir e o que comentar. A comunicação sem fio tornou-se uma plataforma de entrega escolhida para vários tipos de produtos digitalizados, como jogos, músicas, imagens e notícias, bem como redes de apoio pessoal, tarefas profissionais e mobilizações políticas.

A medida em que mais e mais produtos são distribuídos e consumidos online e integrando as redes sociais a outros conteúdos gerados pelos usuários, o comportamento do usuário individual ganha mais relevância para estimular a publicidade. "O número de canais que tiveram receitas anuais de seis dígitos no YouTube cresceu mais de $40 \%$ ano a ano" (YOUTUBE, 2019).

O YouTube não é somente uma mídia, não é somente uma plataforma de conteúdo criado por seus usuários. Para Burguess e Grenn (2009) é mais proveitoso 


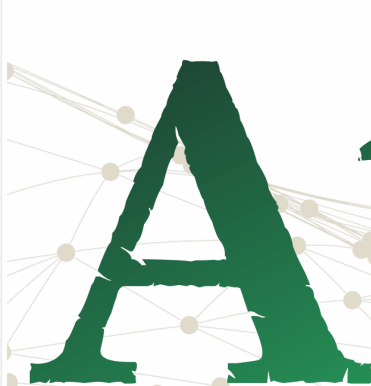

ISSN n²526-8031

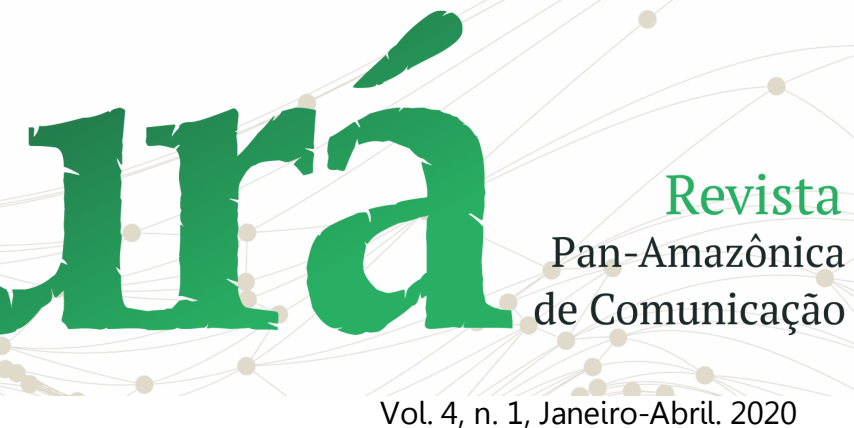

Vol. 4, n. 1, Janeiro-Abril. 2020

DOI: http://dx.doi.org/10.20873/uft.2526-8031.2020v4n1p140

entender o YouTube enquanto uma empresa, atuando como um mecanismo de coordenação entre criatividade individual e coletiva e a produção de significados. Os autores afirmam que sem a noção de como as pessoas usam a mídia em seu cotidiano, qualquer debate sobre impacto cultural ou social está propenso a se tomar uma série de equívocos.

Vale lembrar que a criança é um "nativo digital". Elas veem o celular, por exemplo, como uma ferramenta social indispensável, que serve para além de fazer ligações, mas sim para se comunicarem em redes digitais.

A questão que norteia este artigo é pensar o como YouTube é um canal de consumo espetacular, uma vez que a criança mostra o seu cotidiano, exerce sua criatividade ao postar vídeos em que mostra desde viagens, brincadeiras, passeios, escola, sua cultura infantil.

Youtube: Mídia Encantada
O YouTube, ao trazer em seu slogan o Broadcast Yourself (que na tradução livre significa "transmita-se") faz com que o termo Broadcast que antes era entendido enquanto transmissão por ondas de rádio e televisão, ampliasse o conceito para trazer o protagonismo das pessoas comuns, no sentido de difusão e compartilhamento de suas ideias e pensamentos. O broadcast - ou broadcasting - deixou de ser uma palavra que somente definia um conceito técnico, para tomar gradualmente o sentido de "compartilhamento de mídia em grande escala" (HAUTSCH, 2019). Para Terra (2017), no modelo de socialcast, os usuários produzem, replicam e distribuem conteúdos entre si seguindo a lógica da disseminação de informações de muitos para muitos, oportunizados pelas tecnologias sociais da internet. Para a autora, é nesse contexto de socialcast que os influenciadores digitais surgem e ganham terreno.

Atualmente, temos diversos termos usados para designar o usuário que produz conteúdo no ambiente digital seja 


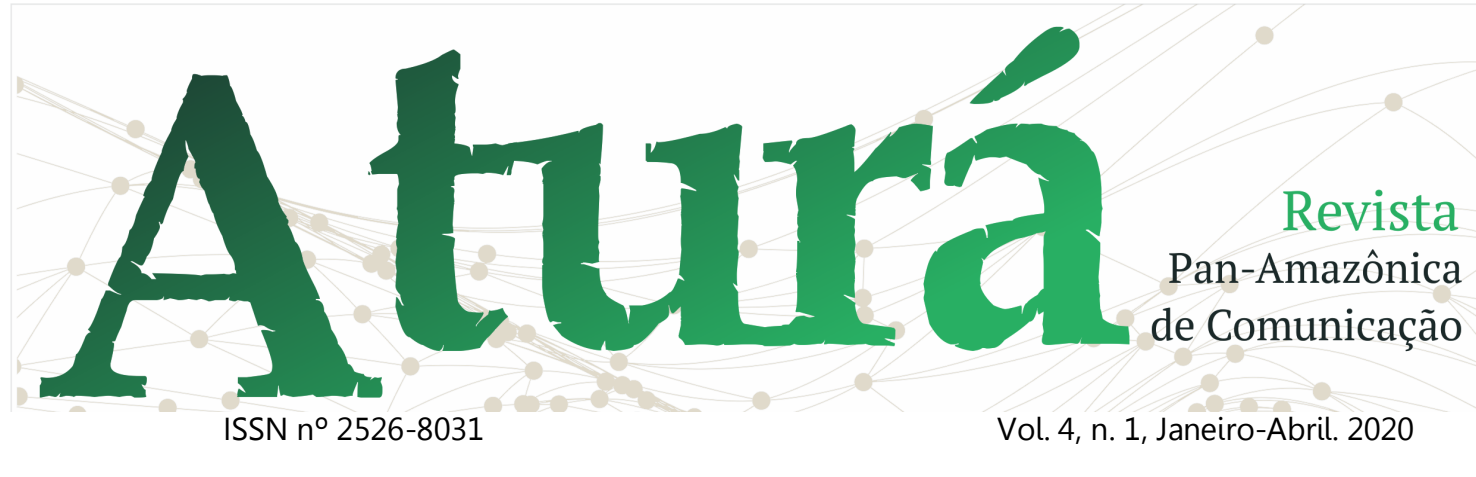

DOI: http://dx.doi.org/10.20873/uft.2526-8031.2020v4n1p140

ele Influenciador digital, formador de opinião online, produtor de conteúdo, creator, youtuber, blogueiro, vlogger.

Um influenciador digital requer uma vida em que seja necessário a produção de conteúdo (criatividade), consistência nessa produção (tanto temática quanto temporal); manutenção de relações, prestígio em uma comunidade e, por fim, influência. Para Karhawi (2016), tornar-se um influenciador pode ser tanto aquele que estimula debates ou agenda temas de discussão em nichos, quanto aquele que influencia na compra de um lançamento de determinada marca. Em ambos os casos, o processo de solidificação em termos de crédito, capital e reputação são os mesmos.

A convergência das tecnologias trouxe para o marketing a possibilidade, e até mesmo a "obrigatoriedade", da junção do marketing tradicional à era digital. $\mathrm{O}$ Marketing 4.0 apresenta os novos caminhos feitos pelos indivíduos na economia digital. Indivíduos esses que buscam, cada vez mais, envolvimento, personalização e relações pessoais. (KOTLER; KARTAJAYA; SETIAWAN, 2017). Observa-se um diálogo entre Jenkins (2009) com Kotler, Kartajaya e Setiawan (2017) ao explanar que:

\begin{abstract}
A convergência exige que empresas de mídia repensem antigas suposições sobre - que significa consumir mídias, suposições que moldam tanto decisões de programação quanto de marketing. Se os antigos consumidores eram previsíveis e ficavam onde mandavam que ficassem, os novos consumidores são migratórios, demonstrando uma declinante lealdade a redes ou a meios de comunicação. Se os antigos consumidores eram indivíduos isolados, os novos consumidores são mais conectados socialmente. Se o trabalho de consumidores de mídia já foi silencioso e invisível, os novos consumidores são agora barulhentos e públicos. (JENKINS, 2009, p. 47).
\end{abstract}

Assim, em Jenkins (2009) enxergase aspectos da estrutura horizontal tratada por Kotler, Kartajaya e Setiawan (2017). Há pontos valorosos nessa nova estrutura para as marcas também, que devem procurar estabelecer um relacionamento horizontal com seus consumidores. Agora ambos estão no mesmo patamar, precisando assim, criar laços de amizade com eles. Com uma maior conexão e troca de informações, as marcas ganharam mais 


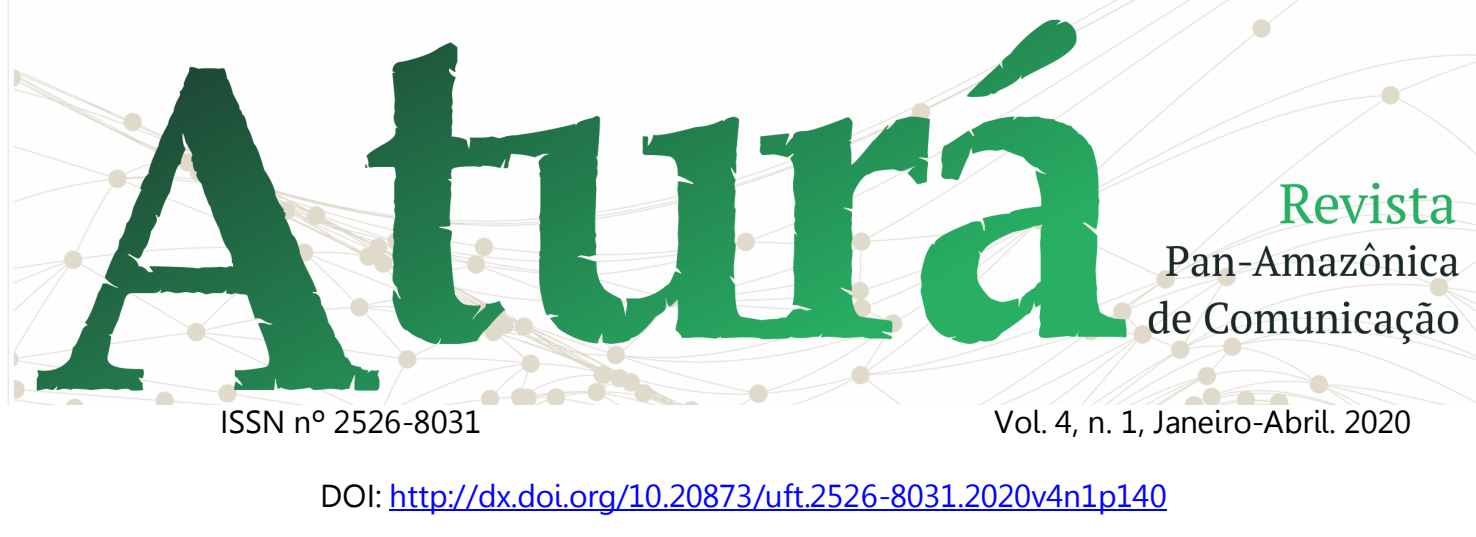

fontes que facilitam o reconhecimento das demandas de mercado. E é neste contexto em que os criadores de conteúdo surgem. O que antes apenas era de responsabilidade dos redatores publicitários para as demandas das mídias, agora reconfigura-se a partir da convergência e faz com que os laços entre marcas e consumidores (usuários) fiquem mais estreitos e humanizados.

\section{O Cotidiano Espetacular}

Observamos os digital influencers enquanto a construção de uma imagem de si, de uma marca que passa a ter valor de troca para empresas dos mais diversos segmentos. Assim como Tomaz (2017), a autora Karhawi (2016) discute que os influenciadores não monetizam apenas o conteúdo que produzem em seus blogs e canais no YouTube, mas eles mesmos, em uma dinâmica próxima à da celebridade. Segundo Karhawi (2016), o influenciador é um sujeito revestido de capital simbólico e que engaja e influencia nichos. O influenciador contemporâneo está nas capas de revistas, em propagandas de televisão, na lista de best sellers das livrarias, estrelando campanhas de grandes marcas.

Karhawi (2016) entende que os influenciadores digitais estão classificados como mercadorias e/ou como veículos de mídia, monetizando não só suas propriedades digitais, como também suas participações (em eventos, por exemplo), sua própria imagem, audiência e credibilidade (legitimada por sua audiência) e passa a ser encarado, na visão de Karhawi como "(...) uma mídia autônoma, uma marca" (KARHAWI, 2016, p. 42-43).

Terra (2017), por sua vez, argumenta que apesar do conceito digital influencers estar em voga tanto na mídia quanto entre os gestores e profissionais dos campos do marketing, comunicação, administração, dentre outros, $\mathrm{o}$ ato de influenciar pessoas não é novo ou inovador. Para a autora, o que vemos é o meio digital potencializando tais ações por seu poder de alcance, impacto, rapidez e viralização. Por outro lado, Terra (2017) 


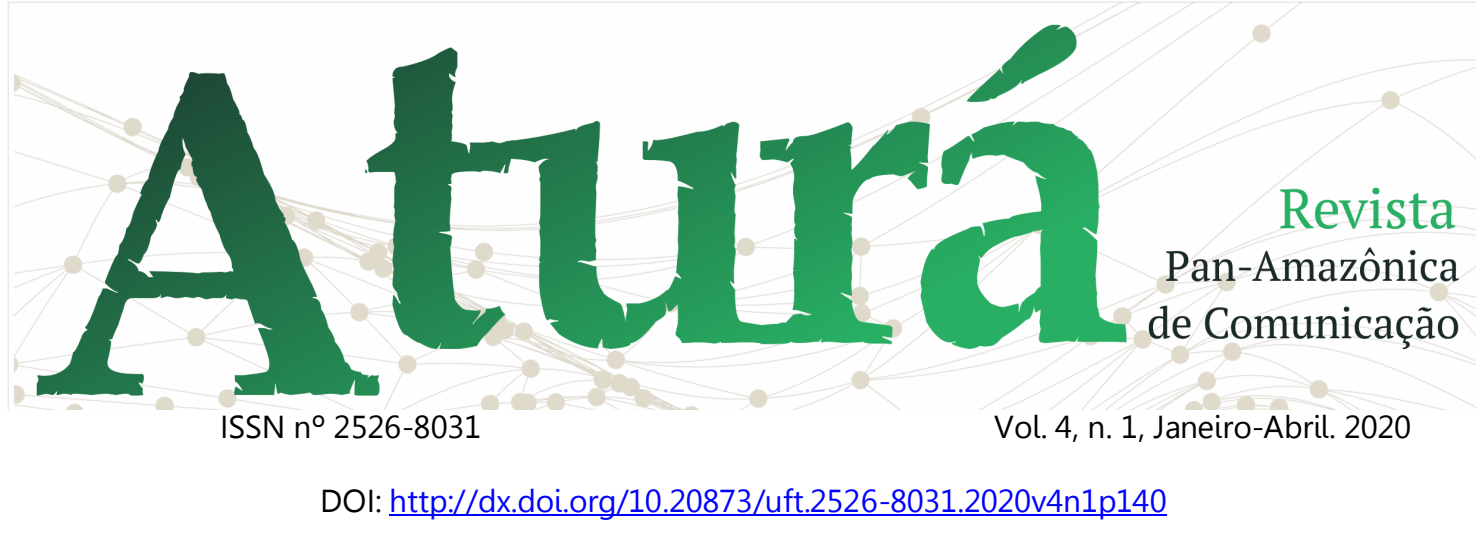

entende que estamos lidando com a midiatização dos indivíduos, na possibilidade de usarmos mídias digitais como instrumento de divulgação, exposição e expressão pessoais.

É de interesse dos próprios influenciadores monetizar a relação com marcas. Eles próprios entenderam que são um canal relevante de comunicação e relacionamento entre as organizações e as audiências que pretendem atingir. Isso tudo com legitimidade e autoridade, uma vez que se transformaram em fontes críveis de consumo de conteúdo. Os influenciadores emitem opiniões, endossam, criticam ou recomendam conteúdos, marcas, produtos e serviços. (TERRA, 2017, p. 89)

Ao serem instrumentos de divulgação das marcas, fazendo parte do planejamento de marketing digital, sendo considerados autoridades em determinados assuntos e ao relatarem suas experiências os influenciadores são desta forma marcas, seus nomes tornamse valiosos. Exemplificando o pensamento de Terra (2017) podemos destacar Laila Brandão, menina paraense de 11 anos, que começou a interagir e produzir vídeos aos
6 anos, mas seu canal só foi ao ar em 2017, quando a menina completou 10 anos. $\mathrm{O}$ Canal de Laila Brandão é administrado, editado e produzido por sua mãe.

Laila atualmente possui mais de 500 mil inscritos em seu canal no YouTube (Figura 1) e mais de 33 mil seguidores no Instagram (Figura 2), lugares em que a menina compartilha seu dia-a-dia, suas experiências e produz conteúdo sobre o universo infantil, como slime 4 . A menina possui vídeos que alcançaram 1 milhão de visualizações. A cada vídeo postado, o público interage e pede novas experiências.

Em entrevista para o portal de notícias DOL (DOL, 2019), a mãe da menina diz que Laila tem parcerias com diversas marcas. "Ela tem parceria com a sorveteria daqui de perto, aí ela come horrores e tem que estar divulgando, em troca da publicidade. Com isso, ela consegue trabalho de modelo, chamam pra peças teatrais, porque ela traz mídia". (DOL, 2018, on-line)

\footnotetext{
4 Massa de modelar bastante viscosa que virou febre entre as crianças.
} 


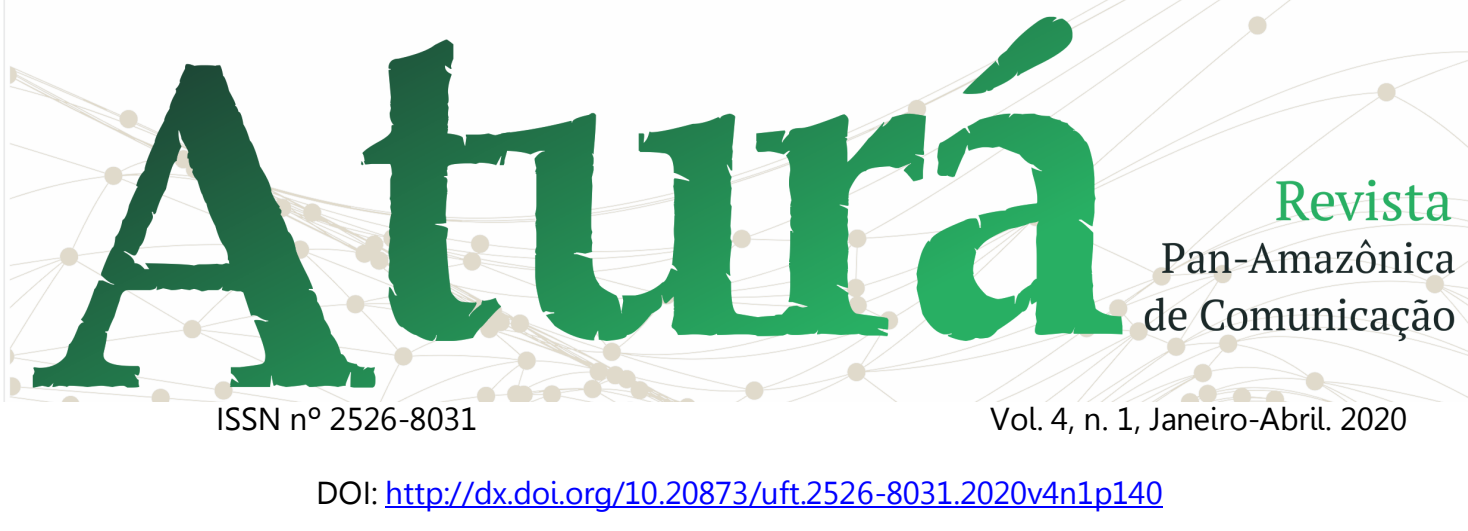

Figura 1 - Canal YouTube de Laila Brandão

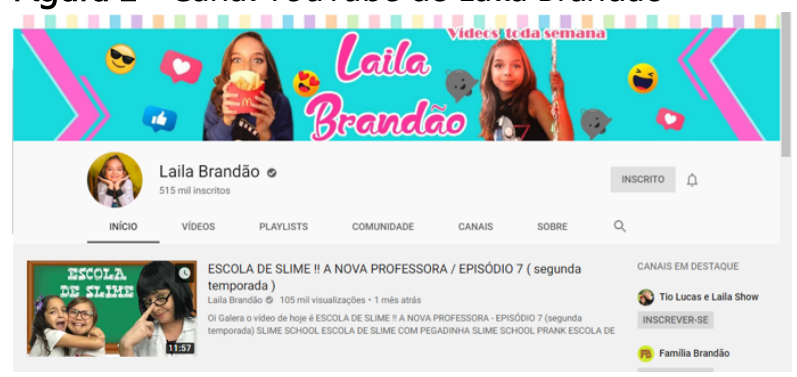

Fonte: Captura de tela

Figura 2 - Instagram de Laila Brandão

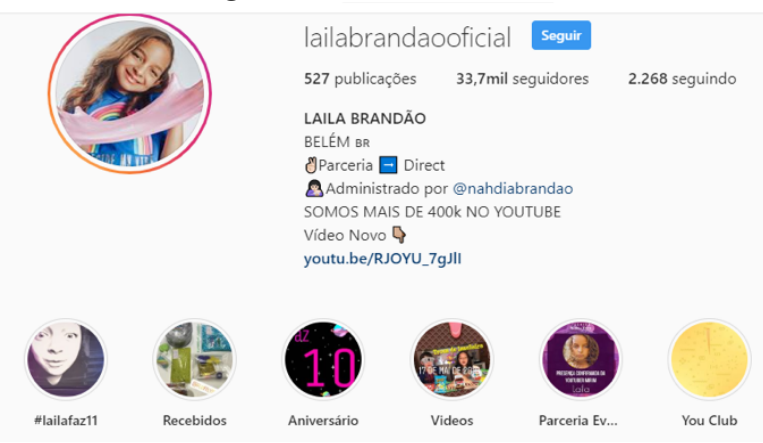

Fonte: Captura de tela

Sibilia (2008), ao falar da intimidade na internet, apresenta o argumento de que estamos diante de uma verdadeira explosão de criatividade e inovação. Isso pode ser observado enquanto temos uma promoção do "eu" na internet. As plataformas digitais mudam o mercado, exigindo mais dos usuários e dos profissionais, tornando estes "criadores de conteúdo". As marcas entendem que o usuário não quer apenas saber o preço do produto e o pagamento, mas quer também acompanhar a marca, seu posicionamento (até mesmo político) e consumir conteúdo diferenciado.

Pensar na criança no contexto da convergência e como ela está inserida na lógica do marketing digital enquanto consumidora e produtora de mídia é entender que o processo de interação entre criança espectadora e criança YouTuber se dá em um ambiente que é familiar para ambas, uma vez que, em muitos dos casos, a criança espectadora também tem seu perfil próprio no YouTube, o ambiente mediador da relação. Isso faz com que o modo como a criança espectadora vê a criança YouTuber seja diferente dos ídolos que ela vê na TV. O YouTuber é muito mais um "amigo", ao acompanhar seus relatos do cotidiano através dos vídeos. Já o jogador de futebol ou a cantora são ídolos mais distantes. A criança sonha em consumir e/ou se tornar famosa como um jogador (a) cantor (a). Essa lógica também se aplica ao YouTuber, uma vez que a criança sabe que tem condições para isso, pois ela possui as 


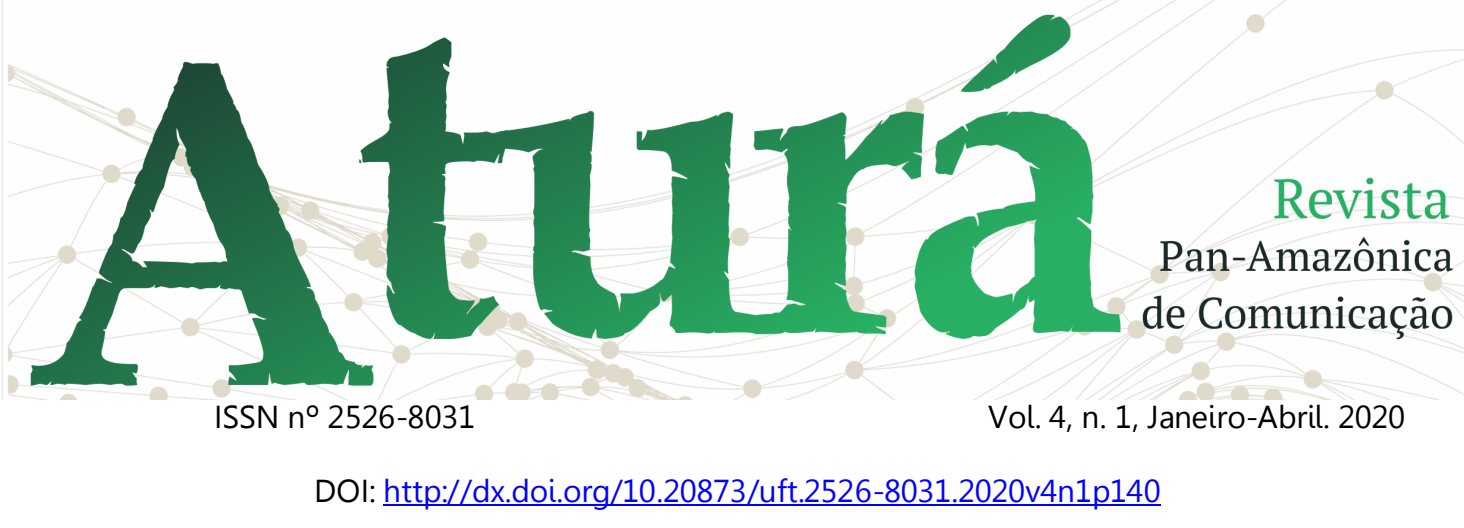

mesmas ferramentas para transformar seus vídeos no YouTube em seus diários, contando seu cotidiano.

\section{A mercantilização do YouTuber mirim}

A vida de uma criança pode ser bastante interessante, do ponto de vista da cultura infantil, ao transformar sua vida pública contando narrativas de seu dia-adia primeiro para familiares, depois amigos de escola e assim para todos que tema acesso na internet. O que se observa neste sentido são os diários íntimos enquanto vitrines globais da rede (SIBILIA, 2008). Os usuários não são apenas protagonistas, mas também são produtores de conteúdo. A vida da criança YouTuber desta forma se torna espetacularizada.

"O lar foi transformado no território de autencidade da verdade, um abrigo onde era permitido ser si mesmo" (SIBILIA, 2008 , p. 62). Com este argumento a autora demostra o quanto o lar, a casa, o quarto são espaços em que nós podemos ser autênticos, livres de julgamentos, o quarto é um lugar de intimidade em que só é convidado a entrar pessoas confiáveis, pessoas intimas. A partir do momento em que compartilhamos, através de blogs ou mais atual Instagram e Youtube estamos produzindo conteúdo para leitores/espectadores. A autora compara esses relatos na internet com os diários e livros, no qual os leitores/espectadores se identificavam com os personagens e construíam sua subjetividade em diálogo com esses jogos de espelho (SIBILIA, 2008) Debord (2003) compreende o Espetáculo na sua totalidade, é simultaneamente o resultado e o modo de produção existente ele não é um complemento do mundo real um adereço decorativo. É o coração da irrealidade da sociedade real. Debord (2003) pensa o espetáculo enquanto a produção de imagens, a valorização da dimensão visual da comunicação, como instrumento de exercício do poder, de dominação social, existe, conforme argumenta. Para o autor, o espetáculo é a afirmação da aparência e a afirmação de toda vida humana, como uma simples aparência. O espetáculo é 


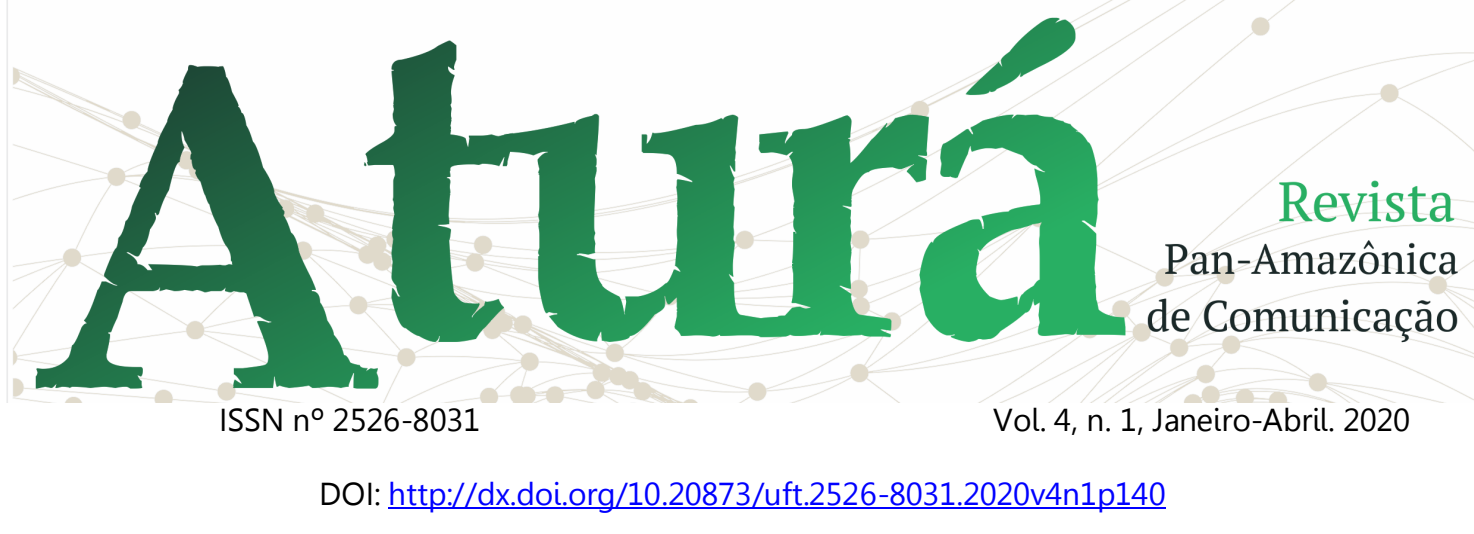

grandioso e positivo, "o que parece bom, é bom por que aparece" (DEBORD, 2003. p. 17)

Debord (2003) define o espetáculo não enquanto um conjunto de imagens, mas uma relação entre social e pessoas mediatizadas por imagens. $O$ espetáculo é a principal produção da sociedade atual. Na sociedade capitalista o espetáculo é o capital a um grau de acumulação que se torna imagem. "A aparência é produto" (DEBORD, 2003, p. 37)

A mídia desempenha importante papel nessa representação social, em anúncios, fotografias, jornais etc., entretanto esta pesquisa estará focada na compreensão das estratégias comunicacionais, estruturais e midiáticas da plataforma YouTube, bem como das interações e desdobramentos de interação social e tecnológica advindos da Criança YouTuber, sendo esta aquela que posta conteúdos nesse espaço e consegue ter uma audiência relevante.

Para Sibilia (2008), falar de si é falar de sua vida de seu cotidiano, sendo assim no YouTube os sujeitos contemporâneos respondem a novas demandas socioculturais, demarcando outras formas de estar no mundo, uma vez que:

As redes sociais digitais, ou os diários
digitais são mais do que um conjunto de
imagens, o espetáculo se transformou em
nosso modo de vida e em nossa visão de
mundo, na forma como eu me relaciono
com os outros e na maneira com que o
mundo se relaciona tudo é permeado no
espetáculo, sem deixar praticamente nada
de fora. (SIBILIA, 2008, p. 44)

A partir disto, ao produzirem vídeos narrando, editando e divulgando partes de suas vidas em espetáculos, as crianças YouTubers buscam também visibilidade, validação, audiência ao transformar sua vida em uma vitrine. Por isso, a autora não se surpreende que os sujeitos contemporâneos adaptem os principais eventos de suas vidas às exigências da câmera e ao que seria de interesse do seu público. Desta maneira, Sibilia (2008) ressalta que o lar é o cenário mais adequado para hospedar a intimidade e, aliado ao pensamento da autora, percebemos que, ao mostrar sua casa, seu quarto a criança YouTuber passa a dividir com seu público sua intimidade, "no lar é 


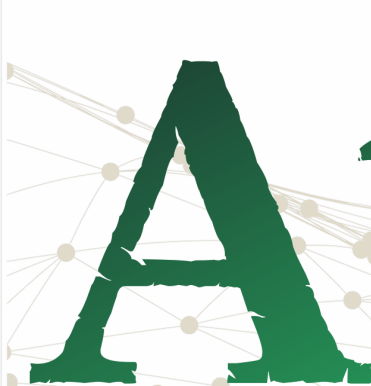

ISSN n²526-8031

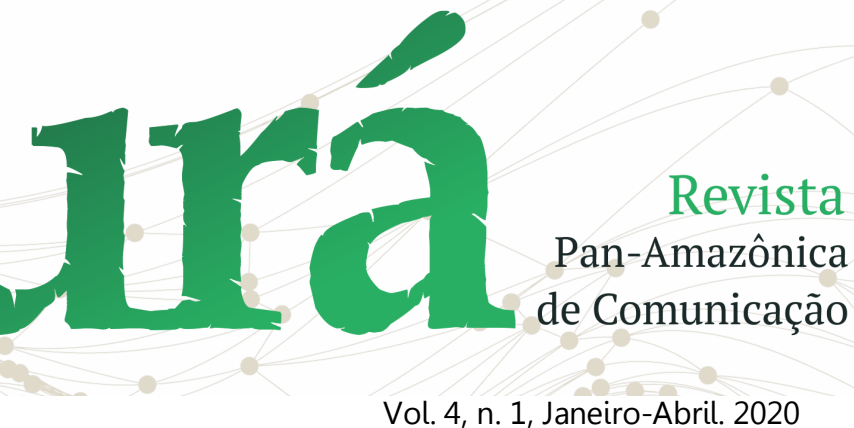

Vol. 4, n. 1, Janeiro-Abril. 2020

DOI: http://dx.doi.org/10.20873/uft.2526-8031.2020v4n1p140

permitido ser si mesmo" (SIBILIA, 2008, p.62). Observa-se desta forma que a intimidade é vista por todos os seguidores/espectadores do canal e que o mais importante é a visibilidade, ou seja, aparecer através de relatos de si. Considerando-se que, na sociedade contemporânea, as representações sociais acontecem de forma dinâmica, no movimento de interação entre sujeitos, na cultura onde estão imersos, ao inseriremse nas redes de significados sociais (e também naquelas digitais), os sujeitos constroem suas representações mediante finalidade prática e são usadas para construir possibilidades de realidades (OLIVEIRA, 2011; OLIVEIRA; MACHADO, 2018).

As imagens como um todo possuem várias percepções, de ordem social, cultural, política e, também, subjetiva. Por isso a necessidade de considerar o espectador, ou seja, o sujeito e sua capacidade perceptiva que, por sua vez, entra em jogo suas crenças e sua história. É preciso ponderar, também, que o YouTuber mirim, como são comumente chamadas as crianças que possuem canal na plataforma YouTube, produz imagens e, ao mesmo tempo, consome conteúdo na mídia, interage e socializa na plataforma. De acordo com Oliveira (2011), as imagens são produzidas para finalidades tanto de usos individuais quanto coletivos. Desta forma, ao revelar suas vivências e experiências através dos vídeos, as crianças fazem chegar à esfera pública temáticas do seu cotidiano, às quais conferem importância (TOMAZ, 2017, p. 15).

A imagem espetacular produzida pelo YouTuber Mirim transforma sua vida, sua aparência (imagem) em produto. Debord (2003, p. 43) fala de "viver aparente", no qual vedetes existem para figurar os tipos variados de estilos de vida e estilos de compreensão da sociedade, o sujeito então é reificado e proclama a prova da sua intimidade como mercadoria. Como é o caso do menino Ryan, que mercantiliza sua imagem e seus relatos. Desta forma, o espetáculo é o momento em que a mercadoria chega a ocupação total da vida social. Dialogando com 


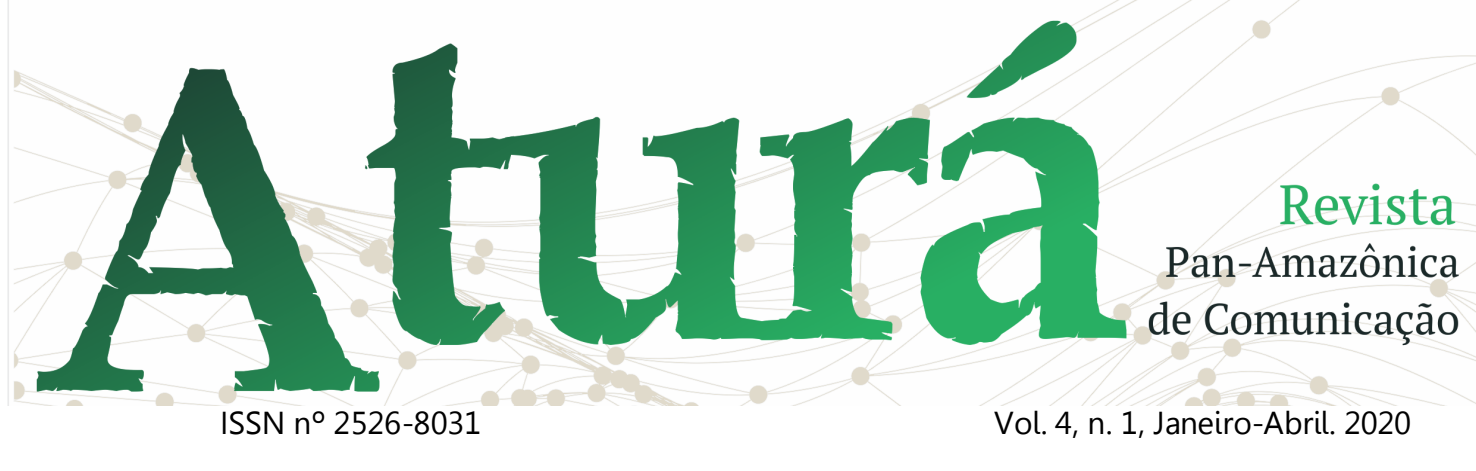

DOI: http://dx.doi.org/10.20873/uft.2526-8031.2020v4n1p140

Debord (2003) e Sibilia (2008) analisa que as relações sociais entre as pessoas passam a ser mediadas por imagens e que o cerne da sociedade de espetáculo é se fazer ver. "O que parece bom e o que é bom aparece" nesse novo pólio de aparência o que fica do lado de fora simplesmente não é importante.

Os usuários podem recomeçar a fazer outro perfil, novos layouts, mais bonitos e um perfil renovado para dar uma nova oportunidade. Os relatos de si desta forma tendem a ser cada vez mais instantâneos, presentes, breves, explícitos. A vida passa ser episódios de uma novela compartilhada. Mecanismos para construir as narrativas do eu. (SIBILIA, 2008, p. 137)

No YouTube, um canal de um YouTuber mirim apresenta vídeos de seu cotidiano. Os vídeos seguem narrativas, contam histórias desde o seu dia na escola, o livro que leu, um passeio ao shopping até mesmo os brinquedos que ganha/compra. Isto pode ser observado na criança espectadora de vídeos do YouTube ao levar crer que aquela vida narrada e mostrada por YouTubers Mirins é a vida sedutora, principalmente aos que querem ganhar presentes e viagens. Os
YouTubers mirins, ao utilizarem de sua criatividade para prender sua audiência, direcionam a construção de seus canais para o olhar alheio. O que se vê nos vídeos é o que é. Para Sibilia (2008, p. 24), "talvez seja ainda mais penoso nesta sociedade de espetáculo, onde só se é o que se vê, neste gesto, tal contingente também é condenado à invisibilidade total". O que se observa é que se você não posta vídeos, não mostra a sua vida, sua intimidade não é exibida no vídeo, a vida não acontece, ela precisa de plateia, de olhares, de curtidas para legitimar o seu sucesso. As possibilidades oferecidas pela internet têm provocado a participação de crianças nesse ambiente, seja pela própria produção realizada por esse público, seja pelos produtos, programas e demais ofertas disponibilizadas na internet. Um exemplo disto é a estratégia de unboxing. Nesta estratégia, observamos que muitas marcas buscam atrair vendas fazendo uso da visibilidade e da audiência dos YouTubers Mirins a partir do envio de brinquedos, os quais devem ser exibidos nos canais do YouTube na forma de 


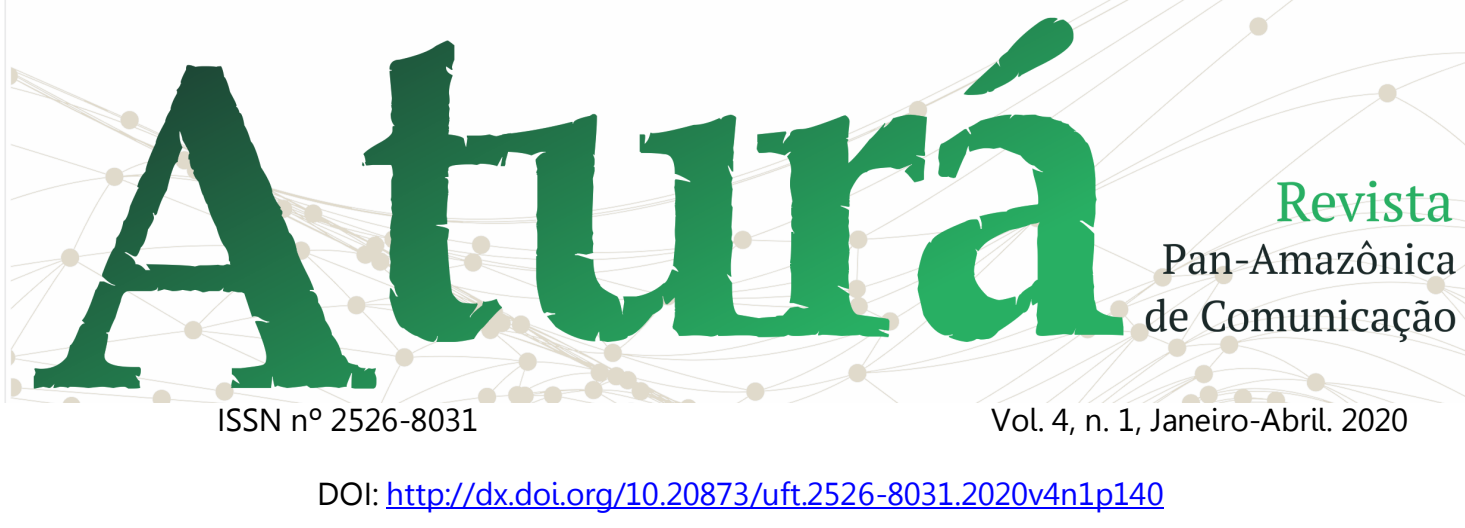

unboxing, como já explicado, significa retirar ou abrir uma caixa. Além disso o canal escolhido pela marca para fazer esse tipo de publicidade possui conteúdo de interesse do público-alvo, por conter elementos do universo infantil. Somado a isto a linguagem utilizada pelos YouTubers Mirins ajuda na construção da experiência no ambiente digital, como Sibilia (2008) analisa o mundo digital, a partir de termos que denotam proximidade $\mathrm{e}$ intimidade com os receptores. Isso pode ser justificado na pesquisa de Correa (2016) a qual aponta a possibilidade de analisar onde as crianças estão inseridas e seus hábitos de consumo de mídia. A inserção dessas crianças provoca mudanças na audiência de Mídia e no investimento publicitário realizado por empresas e organizações. É importante destacar, conforme observa Correa (2016), quando fala que as crianças interpretam o unboxing como brincadeira, divertimento. Entretanto, é nesta linguagem irreverente que a publicidade, através de influenciadores de mídia, encontra seu caminho para persuadir pelo entretenimento. Concorda-se com Oliveira (2011) ao dizer que é no contexto social de todas as formas de socialização da criança, que as representações se efetivam, ou seja, é na dinâmica da relação entre sujeitoobjeto inseridos em um contexto social que constroem, reelaboram opiniões e conceitos de acordo com a história de vida de cada uma. Desta maneira, crianças produzindo vídeos em seu ambiente doméstico, familiar através do YouTube, criando imagens de seu cotidiano, fazem uma representação de sua cultura infantil no digital, compartilhando $\mathrm{o}$ seu cotidiano. $\mathrm{Na}$ sociedade, as representações sociais, das quais trata Oliveira (2011), acontecem de forma dinâmica, no movimento de interação entre sujeitos, na cultura onde estão inseridos. A partir da inserção no todo social, os sujeitos constroem suas representações que tem uma finalidade prática e são usadas para construir uma realidade. Em sua pesquisa, o autor categorizou o brincar no computador como uma marca presente nas representações sociais das crianças, 


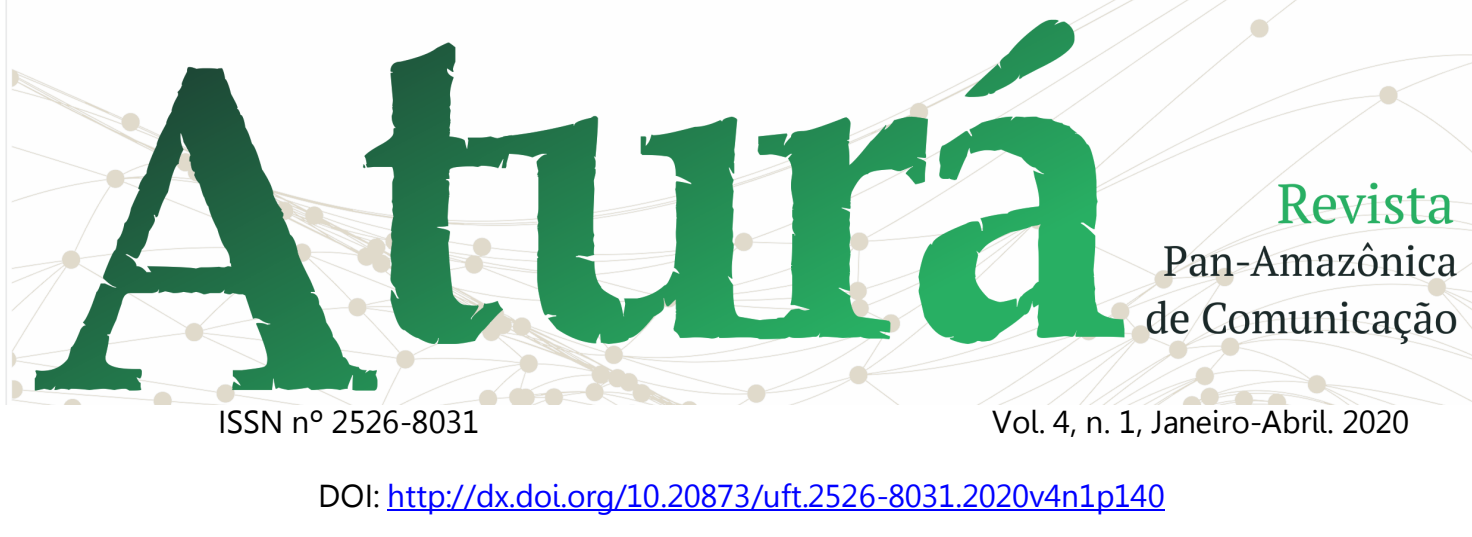

constituindo com isso, uma nova sociabilidade, um novo perfil da infância. O desenvolvimento tecnológico, de acordo com Oliveira (2011), aumentou as possibilidades de espaços de brincar do homo zappiens ${ }^{5}$, dos novos sujeitos históricos constituintes da nova etapa histórica que se apresenta em fragmentos nessa pós-modernidade das representações sociais infantis:

Pode se constituir como um avanço e um valioso instrumento de identificação das apreensões socialmente construídas daqueles que vivem a nova infância. Sabese que as representações sociais são elementos simbólicos que as pessoas expressam mediante o uso de palavras. (OLIVEIRA, 2011, p. 10).

Acredita-se que não estamos diante de uma nova infância, ou do que poderia ser considerado como uma morte desta, mas sim estamos diante de uma infância no digital, a qual possui peculiaridades, expressividades, contextos e linguagens próprias. Assim, ao fazerem uso do YouTube, as crianças se tornam participativas, criadoras, receptoras, ativas, mas também produtos da cultura digital. Mendes (2017) destaca que as estratégias de divulgação também sofreram transformações em relação às mídias tradicionais, uma vez que o discurso publicitário, por exemplo, presente nos vídeos produzidos pelas crianças, não apenas parte de uma relação específica entre YouTubers e Espectador/Consumidor que parecem interagir constantemente nas ferramentas digitais, mas também porque, muitas vezes, o endosso dado pelos primeiros não se apresenta como conteúdo publicitário propriamente dito, mas sim como conversa corriqueira ou sugestão cotidiana, "embalados" numa fachada que enfatiza 0 caráter rotineiro dessa interação.

Duda Guedes pode ser considerada uma das maiores YouTubers Infantis de Belém. Ela possui mais de 1 milhão e 300 mil seguidores inscritos no seu canal do

\footnotetext{
5 Para o autor Oliveira (2011), a lógica da época atual gera a criança zapping, que pula de uma imagem para outra, corta e dispõe imagens simultaneamente.
} 


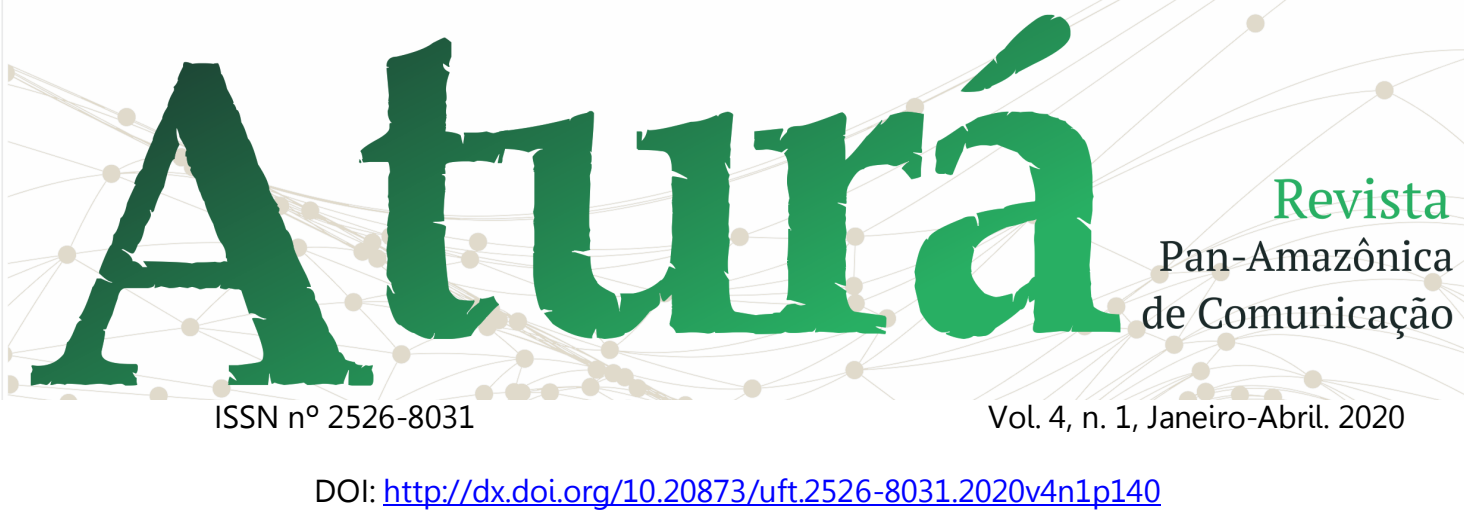

YouTube. Um dos seus vídeos já bateu a marca de 3.7 milhões de visualizações, a menina faz vídeos desde os 9 anos de idade. No vídeo (Figura 3) é um dos muitos que mostram não só sua rotina, como escolha de roupa para uma ocasião especial, mas também a escolha do seu material escolar. Este vídeo de 12 minutos Duda deixa claro no título do vídeo que está comprando seu material e como a imagem mostra (print screen) há a indicação clara de propaganda da Livraria Leitura, localizada em um shopping da cidade de Belém, a própria Duda fala que está comprado seu material neste lugar e ainda traz mensagens como "aqui tem uma infinidade de coisas" mostrando as qualidades da empresa.

Figura 3 - Canal de Duda Guedes

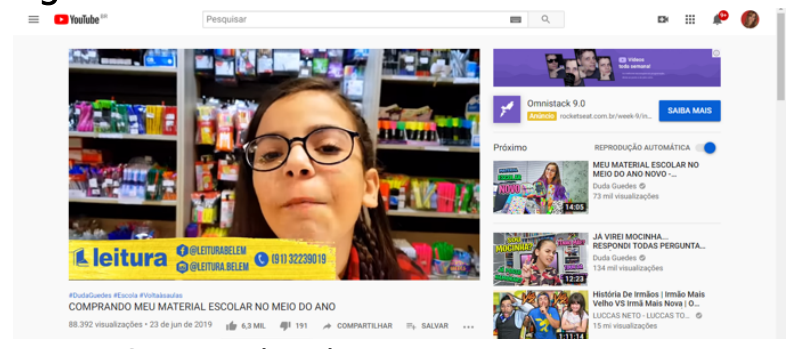

Fonte: Captura de tela
Na sequência do vídeo (Figura 4), a menina mostra detalhadamente os objetos da loja, "tem muito lápis" e depois corta para um plano detalhe mostrando a variedade dos produtos. Este é um tipo de publicidade, não é o formato 30 segundos da televisão, não possui a mesma linguagem, mas herda da televisão o testemunhal, extremamente comum ao usar celebridades para vender. Duda é uma celebridade, ela tem autoridade para vender produtos aos seus seguidores de maneira divertida, falando de criança para criança.

Figura 4 - Canal de Duda Guedes

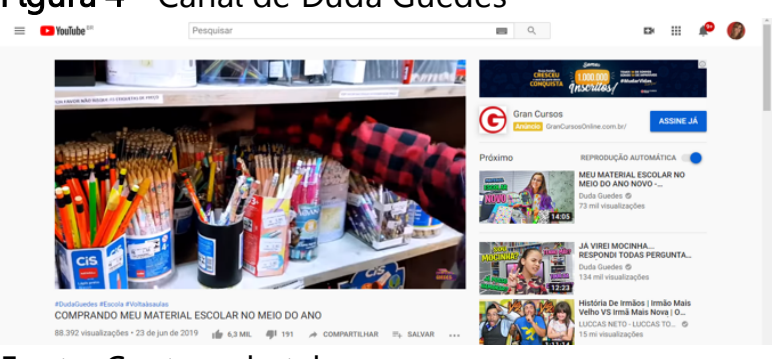

Fonte: Captura de tela

Além de mostrar a compra de seu material, Duda lança um novo vídeo (Figura 5) mostrando em forma de o unboxing os produtos que levou para casa. E mais uma vez vemos o anúncio da 


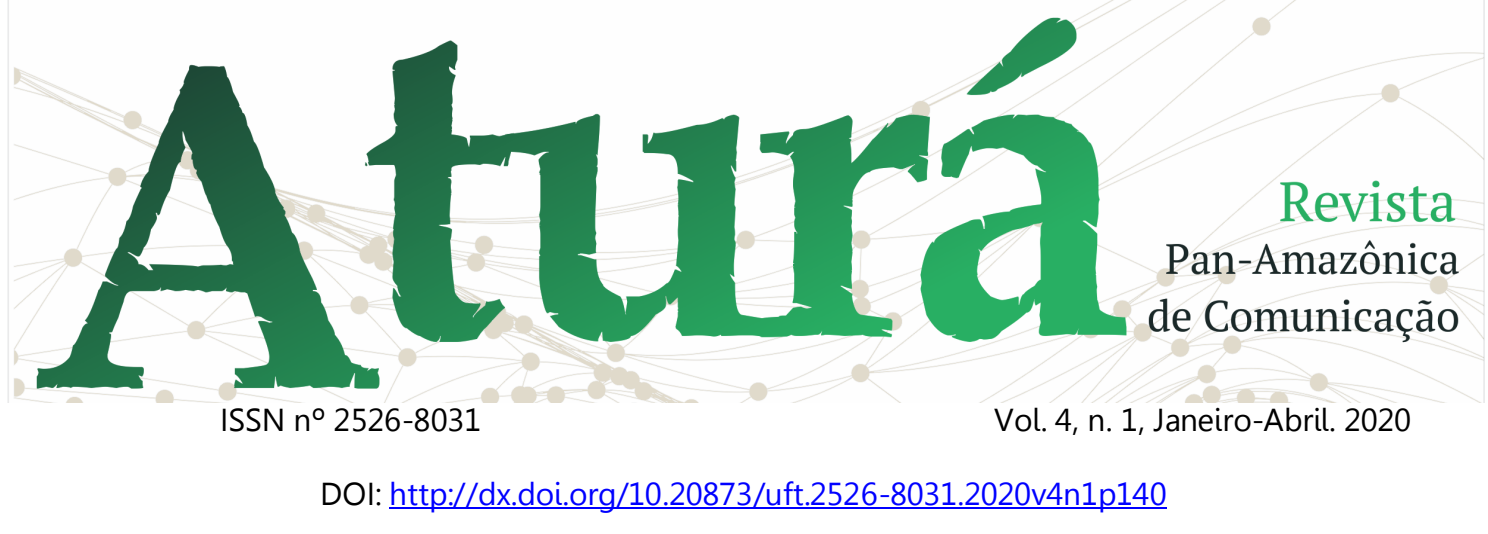

Livraria Leitura além de mencionar que "comprou" o seu material escolar neste lugar. Karhawi (2016) analisa que não são os números que definem a melhor parceria de negócio. $\mathrm{O}$ que define se um influenciador agregará ou não valor a sua marca, conseguirá converter consumidores em clientes ou não, é o engajamento e influência que eles têm em seus nichos e não apenas o número de seguidores ou inscritos nos canais. É essencial que $O$ influenciador seja escolhido de acordo com os valores da empresa e a intenção da campanha/parceria. A Livraria Leitura nesse sentido foi coerente ao escolher Duda, utilizando da YouTubers para fazer uma propaganda criativa, que envolva seus públicos, principalmente o infantil e faz com que as crianças desejem ter os objetos mostrados (comprados) por Duda.

Figura 5 - Canal de Laila Brandão

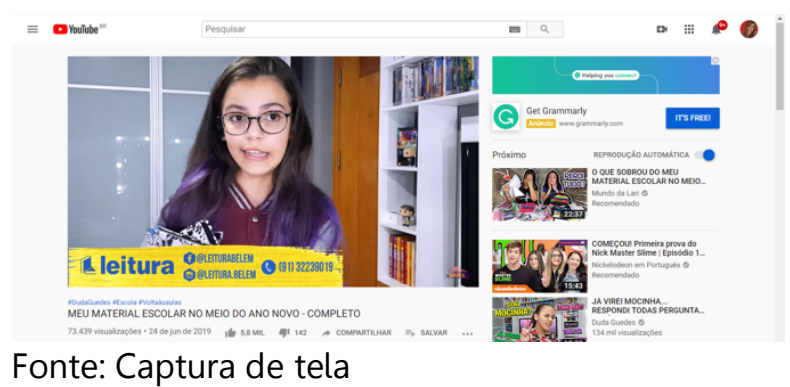

Fonte: Captura de tela

Perez e Trindade

(2017) argumentam que a linguagem utilizada pelos YouTubers faz uso do espontâneo, do erro, do baixo calão, do imperfeito, elementos estes que raramente são observados em outros meios massivos e mais institucionais, como a TV aberta e fechada e os meios impressos, por exemplo. Para os autores, em questão, tudo pode ser transformado em vídeo: ainda que nem sempre o consumo seja do vídeo em si, uma vez que nestas interações consomem-se também "pessoas", seus pontos de vista, uma determinada visão de mundo, um estilo de vida e de cotidiano. Perez e Trindade (2017) analisam na característica do erro, da falha, do natural e do espontâneo como sendo variáveis e diferenciais dos vídeos dos canais no YouTube. O que se tem, neste caso do linguajar das formas de expressão e 


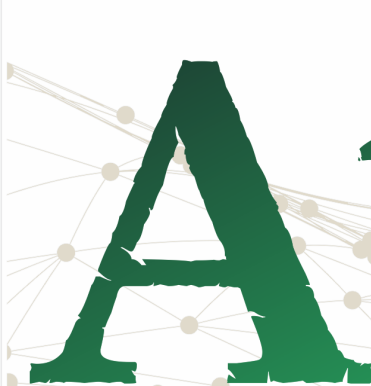

ISSN n²526-8031

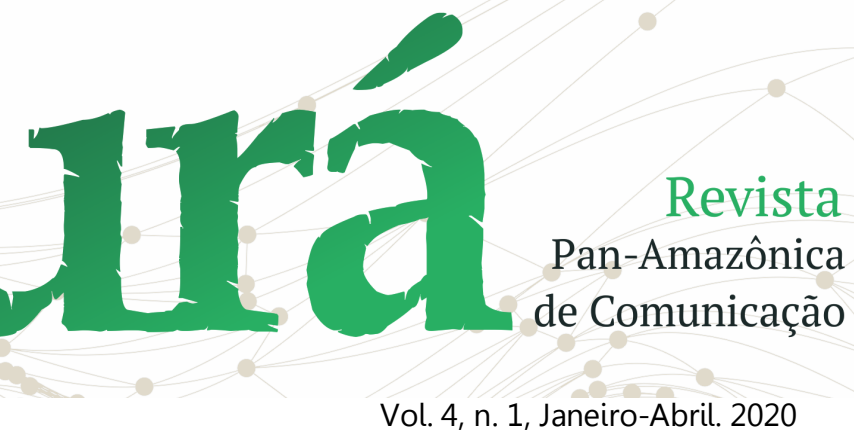

Vol. 4, n. 1, Janeiro-Abril. 2020

DOI: http://dx.doi.org/10.20873/uft.2526-8031.2020v4n1p140

construção de narrativas dos YouTubers, é o desenvolvimento e a utilização de códigos que, mais do que apropriações da linguagem, representam formas de acesso a um determinado grupo, criação de vínculos e construção de espaços de interação e laços, a partir da prática interativa e de identificação com o sujeito que cria o vídeo e o seu espectador.

Muito além de visualizações e inscritos nos canais, Tomaz (2017) argumenta que os comentários e compartilhamentos permitem que os vídeos sejam monetizados, ou seja, façam parte de um complexo e lucrativo programa de anúncios, por meio do qual tanto os produtores de conteúdo quanto a plataforma de vídeos geram receita. Essa dinâmica proporciona, ainda, um processo de celebrização, no qual determinadas crianças saem de uma posição social, em certo sentido, periférica para um lugar de visibilidade.

Concorda-se com Tomaz (2017, p. 38) ao se salientar que "estudar as crianças no YouTube mostra-se um cenário bastante produtivo não só porque ele está sendo cada vez mais ocupado por elas em diferentes práticas". Ainda que essas produções estejam sendo atravessadas por uma série de fatores (roteiros, monitoria dos responsáveis, comparação com outros canais, busca por mais visualizações e inscritos, dificuldade de escrever de crianças recentemente alfabetizadas etc.) o conteúdo de canais infantis é de crianças para crianças. Neste sentido vale ressaltar que os espaços que esta geração digitalizada encontrou, mediada pelas plataformas, objetos e ferramentas móveis, tanto de tablets, smartphones, quanto de computadores, onde a criança brinca e entra em um novo mundo de descobertas e imaginação, tornam-nas alvos para os recursos do marketing por meio dos pequenos astros digitais (LEÃO; PRESSLER, 2017).

Castro (2016) argumenta que não existe espetáculo ou entretenimento sem vedetes, sem o culto às celebridades, ou seja, pessoas como mercadorias. Para o autor o ciberespaço facilita os contatos humanos e o intercâmbio de informações e produtos. Com a evolução das 


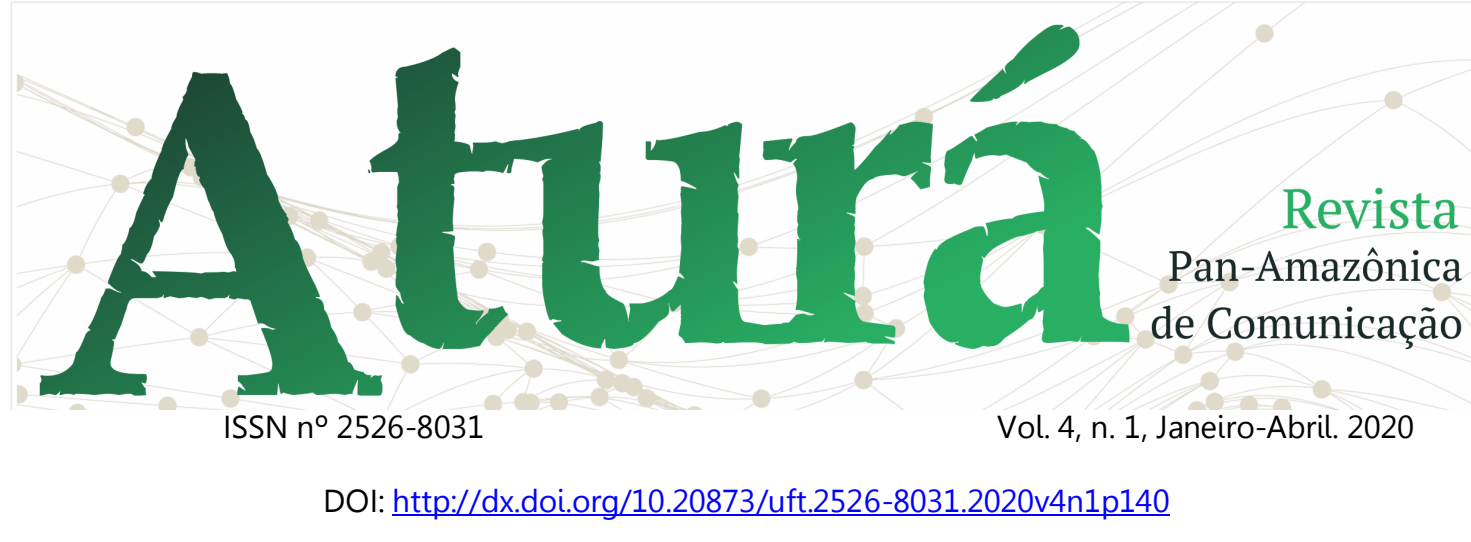

tecnologias o processo e reprodução de imagens tem se intensificado, tornando-as elementos que caracterizam e marcam o destaque desta sociedade de espetáculo ${ }^{6}$. Diante disto, Castro (2016) referencia a imagem como aquilo que nos leva a entrar no mundo da representação, em uma lógica de consumo de imagens e imagens devorando imagens, a busca por visibilidade:

No ciberespaço que é construído pela lógica do espetáculo, como desenvolvemos as imagens se relacionam com as imagens e imagens devoram imagens, nessa profusão de imagens, o excessivo valor de exposição pode atrair o seu oposto um crescente desvalor, uma crise de visibilidade. $O$ perigo é que nesse universo não reste nada de concreto para a vida, uma vez que a imagem, por sua própria natureza, se dirige mais à atividade das pessoas do que por à razão, invoca um pensamento mágico antes que o lógico. (CASTRO, 2016, p. 47)

Neste sentido é possível compreender que o consumo também faz parte da lógica do espetáculo. Tomando como exemplo os YouTubers mirins, que a cada vídeo demonstram um conteúdo

${ }^{6} \mathrm{O}$ autor revisa o conceito de Guy Debord, na obra Sociedade do Espetáculo. novo e diversificado na busca por audiência, é possível perceber como encontramos crianças consumidores destas imagens, destas mini celebridades, o valor apontado pelo autor encontra-se na vida que o YouTuber quer mostrar, um Eu construído para reter atenção de seus seguidores.

Para Martino (2007) a construção do "eu" digital se dá pelo fato que qualquer pessoa é livre para se reinventar conforme os seus gostos. Percebe-se então que a criança, enquanto espectadora de canais de YouTube, aprende e interage com seus ídolos de maneira mais próxima, criando interesse em certos assuntos, interagindo as vezes em tempo real através das lives?.

Assim, observa-se o espetáculo como modos de vida e como o sujeito se relaciona com 0 mundo. Nesta perspectiva:

Ora, os Youtubers que se dedicam a fala de $\mathrm{si}$, de sua intimidade, e conduzem narrativas sobre suas relações afetivas e

\footnotetext{
7 Plataforma que permite assistir e transmitir vídeos em tempo real por meio de uma câmera e de um computador com conexão com a internet.
} 


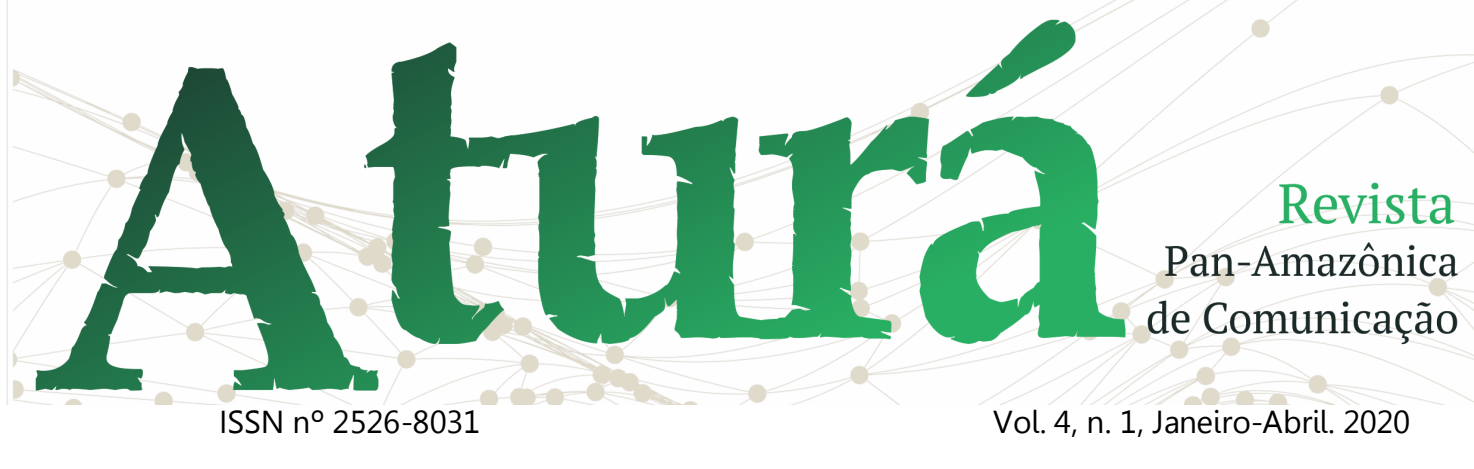

DOI: http://dx.doi.org/10.20873/uft.2526-8031.2020v4n1p140

sobre suas questões pessoais, não somente deixam explícita uma trajetória de vida à medida que vão postando seus vídeos. Exercem também uma forte mediação que acaba por auxiliar outros sujeitos em processos de racionalização de suas próprias experiências e de elaboração de sua auto-identidade, ainda que em uma relação parassocial ancorada na distância física entre o YouTuber e seu público e em um discurso que tem por finalidade ser direcionado a milhões de pessoas, e não a indivíduos singulares. (MESCHIATTI; ZANETTI, 2018, p. 06)

Torna-se válido considerar que compreender a realidade e o mundo desses sujeitos (crianças) nos ajuda a entender suas interações com as novas tecnologias, uma vez que a infância está em constante mudança e dialética contextual. A facilidade de acesso às novas tecnologias pauta a transformação do cotidiano das crianças, sua nova realidade, a apropriação de jogos virtuais, pode tornar as experiências sociais mais lúdicas. Nestas mudanças, há novos sentidos na infância contemporânea, pensar em performance através das audiências seria um caminho para entender como se dão as interações comunicativas das crianças com o YouTube. Ou seja, como se dá a rede de interações sociais infantis por meio dos YouTubers Mirins e das narrativas aí inseridas e desdobradas no contexto de cada receptor.

A criança que possui ferramentas de acesso à internet e mantém uma postura ativa diante dos diversos meios, interagindo, criando e publicando seu próprio conteúdo por exemplo, não será passiva diante dos anúncios publicitários e mensagens pensadas nos formatos tradicionais e lineares entre emissor e receptor. Talvez as empresas, o mercado e os veículos de comunicação precisem repensar suas estratégias para conquistar este público: para atingi-lo é necessário estar presentes em várias plataformas e meios, possibilitando assim, compartilhamento de informações entre as crianças, tornando mais próxima sua relação com os pequenos consumidores. Por isto vemos a mudança que antes na televisão as apresentadoras eram as grandes influenciadoras infantis, hoje percebemos isto acontecer por meio dos YouTubers Mirins ganhando espaço e sendo destacados protagonistas nas narrativas criadas e idealizadas 


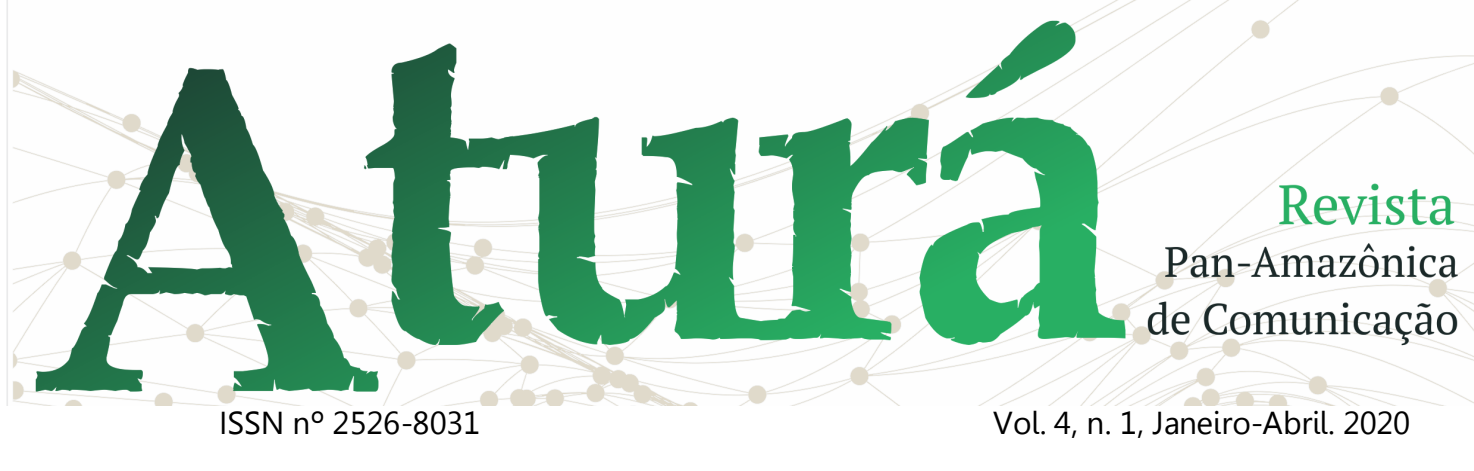

DOI: http://dx.doi.org/10.20873/uft.2526-8031.2020v4n1p140

envolvendo produtos, marcas e a informação que estará disponibilizada, bem como esta será divulgada, nestas mídias não apenas digitais, mas de ponte com as interações entre imagens, sujeitos e social.

\section{Referências}

BURGESS, Jean; GREEN, Joshua. YouTube e a revolução Digital: Como o maior fenômeno da cultura participante transformou a mídia e a sociedade. São Paulo: Aleph, 2009.

CASTELLS, Manuel. $O$ poder da comunicação. Rio de Janeiro: Paz e Terra, 2015.

CASTRO, Valdir José de. O espetáculo em Bits na cibercultura. In: COELHO, Claudio Novaes Pinto \& CASTRO, Valdir José de (orgs). Cultura, comunicação e espetáculo. São Paulo: Paulus, 2016.

CORRÊA, Luciana. Geração YouTube: Um mapeamento sobre o consumo e a produção de vídeos por crianças. ESPM Media Lab: São Paulo, 2016. Disponível em: http://criancaeconsumo.org.br/wpcontent/uploads/2018/09/MediaLab_Luciana_Correa_2016.pdf. Acesso 12 dez. 2018.

DEBORD, Guy. A Sociedade do espetáculo. Rio de Janeiro: Contraponto, 2003.
DOL, Diário Online. Conheça os famosinhos paraenses do Youtube. 2018. Disponível em: $<$ https://www.diarioonline.com.br/noticia s/para/noticia-532735-conhecaosfamosinhos-paraenses-doyoutube.html\#>. Acesso em: 6 set. 2019.

HAUTSCH, Oliver. O que é broadcast? 2009. Disponível em: <https://www.tecmundo.com.br/playerde-video/2026-o-que-ebroadcast-.htm>. Acesso em: 6 set. 2019.

JENKINS, Henry. Cultura da Convergência. Tradução Susana Alexandria. - 2 ed. - São Paulo: Aleph, 2009.

KARHAWI, Issaaf. Influenciadores digitais: o Eu como mercadoria. In: Tendências em Comunicação Digital. Org. Elizabeth Saad, e Stefanie Silveira. São Paulo, ECA-USP, $2016 . \quad$ Disponível em: http://www.livrosabertos.sibi.usp.br/portal delivrosUSP/catalog/download/87/75/365 -1 ? inline $=1$. Acesso em setembro de 2019.

KOTLER, Philip; KARTAJAYA, Hermawan; SETIAWAN, Iwan. Marketing 4.0: do tradicional ao digital. Tradução Ivo Korytowski. Rio de Janeiro: Sextante, 2017.

LEÃO, Danuta; PRESSLER, Neusa. Youtuber Mirim: Formas de Interação e Consumo. In: PROPESQ PP. VIII PróPesq - Encontro de Pesquisadores em Publicidade e Propaganda. Recife, 2017. Disponível em: https://20ccfb7f-2aea-41e5-9b4ac5ea67ac6651.filesusr.com/ugd/bb9c7e_6 


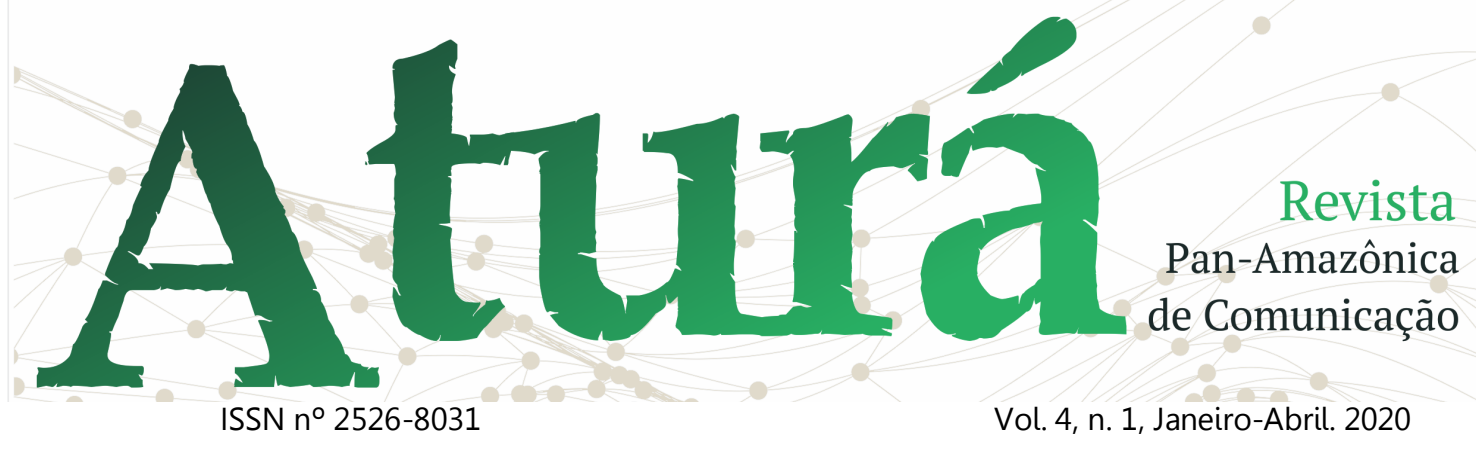

DOI: http://dx.doi.org/10.20873/uft.2526-8031.2020v4n1p140

adeeebc2c4b44b2b83e2ec92fa2160d.pdf. Acesso em agosto de 2019.

MARTINO, Luís Mauro de Sá. Estética da Comunicação: Da consciência comunicativa ao "eu"digital". Petrópolis, RJ: Vozes, 2007.

MENDES, José Maria. Endosso Publicitário no YouTube: Gestão da Proximidade e ocultação da equipe na divulgação do Novo Ensino Médio. In: PROPESQ PP. VIII PróPesq PP - Encontro de Pesquisadores em Publicidade e Propaganda. Recife. 2017. Disponivel em: https://20ccfb7f2aea-41e5-9b4ac5ea67ac6651.filesusr.com/ugd/bb9c7e_f 1d63266cfe64f6cba4d12c5433ab5a3.pdf. Acesso em agosto de 2019.

MESCHIATTI, Amanda; ZANETTI, Daniela. Mulheres Youtubers e Narrativas Íntimas: racionalização e compartilhamento dos afetos. In: Anais XXVII Encontro Anual da Compós, 2018. Disponível em: http://portal.pucminas.br/compos2018/in dex.php?file=noticia\&id $=3652$. Acesso em agosto de 2019.

OLIVEIRA, Luis Carlos Carvalho. Homo zappiens: as Representações Sociais da Nova Infância na Sociedade Digital. Revista Hipertexto. v.1. n1. 2011. Disponivel em: http://www.latec.ufrj.br/revistas/index.php ?journal $=$ hipertexto $\&$ page $=$ article\&op $=v i$ ew\&path\%5B\%5D =42\&path\%5B\%5D =11 1. Acesso em agosto de 2019
OLIVEIRA, A. M.; MACHADO, M. Adolescência, cultura e sociedade do espetáculo. Revista Observatório, v. 4, n. 2, p. 458-479, 1 abr. 2018.

PEREZ, Clotilde; TRINDADE, Eneus. Consumo midiático: Youtubers e suas milhões de visualizações. Como explicar?. In: COMPÓS XXVI - Encontro Anual da Compós, Faculdade Cásper Líbero, São Paulo - SP, 06 a 09 de junho de 2017. Disponível em: http://www3.eca.usp.br/sites/default/files/ form/biblioteca/acervo/producaoacademica/002844038.pdf. Acesso em agosto de 2019.

SIBILIA, Paula. O show do eu: a intimidade como espetáculo. São Paulo: Nova Fronteira, 2008.

TERRA, Carolina. Do broadcast ao socialcast: apontamentos sobre a cauda longa da influência digital, os microinfluenciadores. Revista Communicare. Volume 17 - Edição especial de 70 anos da Faculdade Cásper Líbero. Disponível em: https://casperlibero.edu.br/wpcontent/uploads/2017/09/Artigo-4Communicare-17- Edi\%C3\%A7\%C3\%A30Especial.pdf. Acesso em setembro de 2019

TOMAZ, Renata. O que você vai ser antes de crescer: Youtubers, Infância e Celebridade. Tese de Doutorado. Escola de Comunicação, Universidade Federal do Rio de Janeiro, UFRJ. Rio de Janeiro, 2017. Disponível em: http://www.pos.eco.ufrj.br/site/download. 


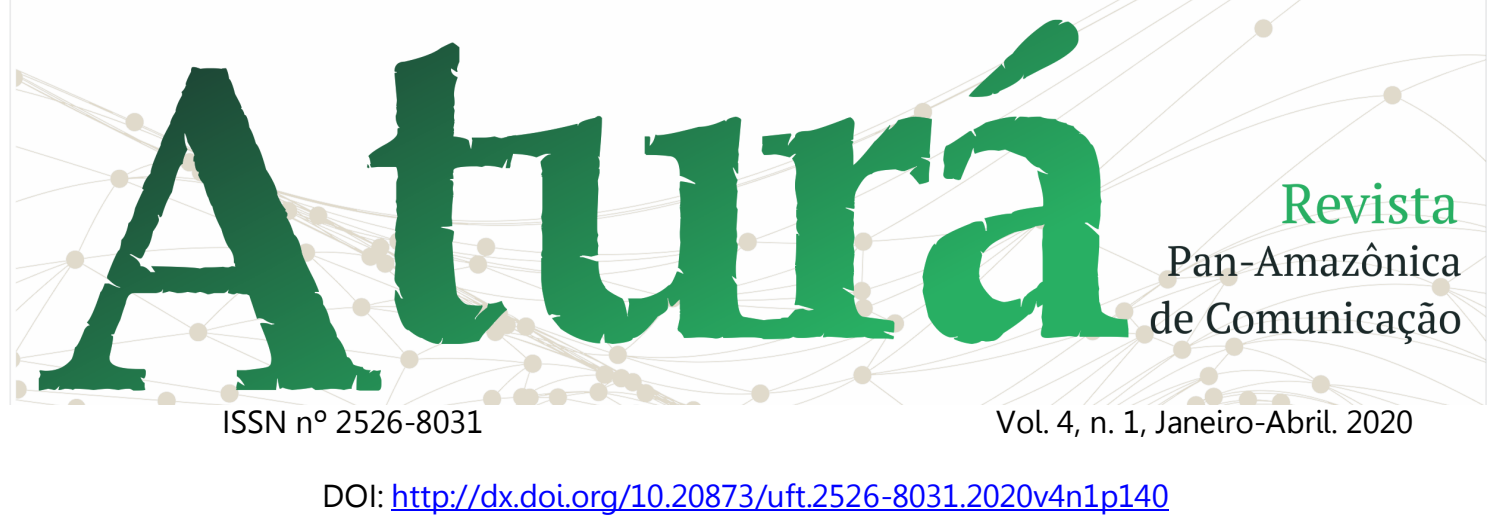

php?arquivo=upload/tese_rtomaz_2017.p

df. Acesso em agosto de 2019.

YOUTUBE. Youtube para a imprensa. 2019.

Disponível em:

$<$ https://www.youtube.com/intl/pt-

BR/yt/about/press/>. Acesso em: 7 ago.

2019. 